\title{
Microfinance, Financial Literacy, and Household Power Configuration in Rural Bangladesh: An Empirical Study on Some Credit Borrowers
}

\author{
Faraha Nawaz $^{1,2}$
}

Published online: 27 May 2015

(c) The Author(s) 2015. This article is published with open access at Springerlink.com

\begin{abstract}
The paper explores the impact of microfinance on multidimensional constructs of empowerment and the catalysts thereof. The reference point for analysis in the paper is the women microfinance borrowers' self perception about their life transmutation as well as that of household power configuration. Unlike other recent research papers on the topic that focus on women's economic empowerment, this paper focuses on both economic and socio-cultural empowerment. The paper is based on both primary and secondary data. Qualitative primary data were collected from women beneficiaries of microfinance in Bangladesh. This paper argues that microfinance can be a useful empowerment tool that can transmute women's economic position and power relationships, but only when combined with financial literacy. It concludes that financial literacy is more important than access to credit and should be the focus of all future microfinance programs.
\end{abstract}

Résumé L'article explore les conséquences de la microfinance sur la notion multidimensionnelle de l'autonomisation et les catalyseurs de celle-là. Le point de référence de l'analyse dans cet article est la propre perception des femmes emprunteuses de la microfinance sur leur transmutation de la vie ainsi que celle de la configuration de l'alimentation domestique. Contrairement à d'autres travaux de recherche récents sur le sujet portant sur l'autonomisation économique des femmes, ce document s'intéresse à l'autonomisation économique et socioculturelle. Cet article repose sur des données primaires et secondaires. Les données primaires qualitatives ont été recueillies auprès de femmes bénéficiaires de la microfinance au Bangladesh. L'article affirme que la microfinance peut être un outil d'autonomisation utile, capable de transformer la situation économique des femmes et les

Faraha Nawaz

faraha.nawaz@gmail.com

1 University of Rajshahi, Rajshahi, Bangladesh

2 Flinders University, Adelaide, Australia 
relations de pouvoir, à condition d'avoir des connaissances financières. Il conclut que ces connaissances sont plus importantes que l'accès au crédit et qu'elles devraient être au cœur de tous les programmes de microfinance à venir.

Zusammenfassung Der Beitrag untersucht, wie sich die Mikrofinanzierung auf das multidimensionale Empowerment-Konstrukt und dessen Katalysatoren auswirkt. Der Analysebezugspunkt hierbei ist, wie weibliche Mikrokreditnehmer ihre Lebenswandlung und die Machtkonfiguration im Haushalt wahrnehmen. Anders als andere jüngere Forschungsarbeiten zum Thema wirtschaftliches Empowerment von Frauen, konzentriert sich dieser Beitrag neben dem wirschaftlichen auch auf das sozio-kulturelle Empowerment. Er basiert auf primäre und sekundäre Daten. Dabei wurden qualitative Primärdaten über weibliche Nutzträger der Mikrofinanzierung in Bangladesch gesammelt. Es wird dargelegt, dass die Mikrofinanzierung ein nützliches Empowerment-Instrument sein kann, dass die wirtschaftliche Stellung und Machtbeziehungen von Frauen verändern kann; allerdings nur, wenn entsprechende Finanzkenntnisse vorhanden sind. Man kommt zu dem Schluss, dass Finanzkenntnisse wichtiger sind als der Zugriff auf Kredite und diese somit im Mittelpunkt aller zukünftigen Mikrofinanzierungsprogramme stehen sollten.

Resumen El presente documento explora el impacto de las microfinanzas sobre el constructo multidimensional del empoderamiento y los catalizadores del mismo. El punto de referencia del análisis en este documento es la propia percepción de las prestatarias de microfinanzas sobre su transmutación vital así como también la de la configuración del poder doméstico. Al contrario que otros trabajos de investigación sobre el tema que se centran en el empoderamiento económico de las mujeres, el presente documento se centra tanto en el empoderamiento económico como en el empoderamiento sociocultural. El documento se basa tanto en datos primarios como secundarios. Los datos primarios cualitativos fueron recopilados a partir de beneficiarias de microfinanzas en Bangladesh. El documento argumenta que las microfinanzas pueden ser una herramienta de empoderamiento útil que puede transmutar la posición económica de las mujeres y las relaciones de poder, pero sólo con conocimiento financiero. Concluye que el conocimiento financiero es más importante que el acceso al crédito y debe ser el foco de atención de todos los futuros programas de microfinanzas.

Keywords Power relation - Empowerment · Microfinance - Agency · Income generating activities

\section{Introduction}

Since 1991, Bangladesh has had a female prime minister, but women in general have less access to political positions, managerial or technical jobs, occupational choices, equal pay for equal jobs, or social status. The women's economic and social status has improved in the recent past, though, for example, the country has gained 107 places in the Gender Development Index (GDI) compared to the Human Development Index 
(HDI) ranking of 142 (www.undp.org). However, women in Bangladesh, in general, in formal or informal economic activities, have to struggle to reconcile activities outside the home with their traditional household roles and family responsibility. The need for women's empowerment, especially those in rural areas, has emanated from the harsh social scenario of the country (Goswami 1998, p. 45).

Women's 'power struggle' is also a result of low employment and investment opportunities. This situation fostered the emergence of Non-Governmental Organizations (NGOs) providing the twin services for poverty alleviation and women's empowerment (Begum 2003, p. 5). Collateral-free microfinance programs became the main catalyst for both. Today's use of the expression 'micro financing' has its root in the 1970s when microfinance pioneer, the Nobel laureate Professor Mohammad Yunus, introduced the Grameen Bank model. Since then, the NGO sector has achieved remarkable success in providing collateral-free credits to the rural women for addressing the problem of poverty (Mahtab 2007, 82). The Grameen Bank also promoted social and financial discipline by emphasizing activities through its social and environmental development programs, aimed at making the rural poor women more productive and better contributors in improving their standard of living (Kabir 2002 cited in Siddiquee and Faroqi 2009, p. 248), and hence empowerment.

Persuaded by the success of the Grameen Bank in providing collateral-free small loans to the poor for income generating activities, a large number of NGOs, such as BRAC, ASA, or Proshika joined the microfinance programs for poverty alleviation in Bangladesh (Mahtab 2007, p. 82). A new wave of microfinance innovations energized the sector. The Palli Karma-Sahayak Foundation (PKSF), a non-profit company created by the Bangladesh Parliament, sponsored credit programs where $82 \%$ of the beneficiaries were women. The credit facilities increased the capacity of rural women to be involved in both farming and non-farming activities. Most studies reveal that the credit was used mainly for generating self-employment (Rahman 1996; Lovell 1992; Ray 1987 and Yunus 1983, cited in Sarkar 2000, p. 3) that reduced poverty and empowered the women. There are critiques, though, who debate the role that microfinance organizations' play in the empowerment of women. Nonetheless, an important question is what is the target group's or the beneficiaries' (i.e. the women's) position in this debate? This paper is set to address this question. It explores the impact of microfinance on the multidimensional construct of empowerment and its contributing factors. The reference point of analysis in the paper is the women microfinance borrowers' own perception about their life transmutation including the (perceived) transformation in household power configuration.

The paper is divided into four sections. The first section, research methodology, covers all actions including the research approach, variables, data collection tools, method (including the sites, sampling, and data collection process), and data analyses. The second section provides a brief overview of microfinance and women in Bangladesh. It also covers the microfinance programs of the two selected instrumental cases (the BRAC and ACD). The third section highlights a range of relevant literature relating to the role played by microfinance programs on women's empowerment. It identifies gaps in those works that this paper will address. By comparing the women's position in selected criteria before and after joining the 
microfinance programs, the fourth section highlights the critical role of microfinance on women's economic and socio-cultural empowerment at the household and community arenas.

\section{Research Methodology}

Most research studies on women empowerment have largely focussed on a financial or an economic paradigm without considering multidimensional construction of empowerment. The current research extends beyond the financial paradigm of empowerment and encompasses its social cultural dimension. Within the theoretical foundation, the research analyzes whether microfinance has brought any changes in gendered allocation and utilization of resources, which is generally in the men's domain and control.

Women's empowerment in this paper is analyzed from two dimensions: (i) Economic (ii) Socio-cultural. Economic empowerment focuses more on the 'power to' dimension of power relationships in relation to higher access to credit and savings and other economic resources such as business training. All these factors improve the economic position of women leading to better bargaining abilities in their home and community (Basargekar 2010) and ultimately 'power to.' The indicators of economic empowerment at the household level include women's involvement in income generating activities, access to and control over loan utilization, and control over income and expenditure. Economic empowerment can be analyzed with questions like who keeps household earnings and who has a say in household expenditure (Kabeer 1996 cited in March et al. 1999, p. 19).

Socio-cultural empowerment encompasses the 'power with' dimension of power relationship that allows women to examine, articulate, organize, and fulfill their own interests and to link with other women's and men's organizations for change (Basargekar 2010, p. 33). Socio-cultural dimensions of empowerment encompass women's decision making agency, mobility in the public domain, and changes in perception of and reaction toward spousal violence (adapted from Kabeer 1996; Moser 1993 cited in March et al. 1999; Malhotra et al. 2002).

Decision making agency includes women's ability to take both minor decisions (like small household purchase, emergency health care, and family matters) and major decisions (like large customer purchases, children's education, family health, house repairs, leasing land etc.) (Hashemi et al. 1996; Cleland et al. 1994 cited in Kabeer 1998).

The indicators of women's mobility in the public domain encompass women's freedom of movement, especially mobility accessing markets (for purchasing essential goods), medical needs (to go for treatment), and leaving the village (for visiting cinema, restaurants, relative, and friends' houses). These indicators have been taken from Kabeer (1996 cited in March et al. 1999), Hashemi et al. (1996), and Malhotra et al. (2002) and used as a guide for data collection and analyses.

Spousal violence from the women's perspective refers to both physical and verbal violence against women at the household arena. The indicators of spousal violence against women includes a woman's fear of the husband, physical assault by 
the husband, a woman's perception of and reaction toward spousal violence, and a woman's protest against such incidences on their own or with the help of someone else in the neighborhood and community (adapted from Jejeebhoy 1997 cited in Kabeer 1998).

The researcher's epistemological position drove her choice of methodology, guiding her to choose inductive (qualitative) research and data collection techniques to conduct the study. The present study follows a qualitative strategy with inductive reasoning, i.e., based on the on-going construction of reality by both the participants and the researcher. Broader generalization and theory formation are attempted. This study emphasizes 'words' rather than 'numbers' and gives higher priority on the participants' ideas, actions, and method of constructing 'realities.' Moreover, the author focused on the process - why and how things happened-rather than the outcomes. Therefore, importance has been given on the 'depth' rather than the 'breadth' as well as on the participants' real world. The study also followed a triangulation approach involving different qualitative methods of data collection such as semi-structured in-depth interview, focus group discussion and observation, and multi-perspectives analyses involving both the participants and NGO officials.

The data were collected to explore the processes by which microfinance may perhaps make a difference to the lives of the borrowers. Two villages (Chokkapashiya and Dewyanpara under Usufpur and Borogachi Union Parishad-the lowest tier of local government) were selected for the purpose because of physical accessibility (from the nearest city-Rajshahi), existence and length of the microfinance programs, and number of women participating in the microfinance program. One national NGO, the BRAC (Bangladesh Rural Advancement Committee), and a local NGO, the ACD (Association for Community Development), were chosen. The BRAC has been working since the independence of Bangladesh in 1971 to alleviate poverty and to empower women. Although the Grameen Bank is the pioneer of microfinance in Bangladesh, the BRAC is considered to be the largest and most diversified NGO with wider functional coverage especially in rural areas focusing on poor women. The ACD has been selected due to its diversified activities, e.g., sustainable development programs for women in the villages selected for the study. Information relating to the operation of each organization was collected through one-to-one interviews with a total of ten NGO officials working at the field level or at the headquarters of the organizations and also by attending their weekly and monthly meetings.

Since the main purpose of the fieldwork was to have a complete in-depth understanding of the selected cases, purposive sampling sizes were achieved through the 'theoretical saturation technique' (i.e., the marginal case did not bring additional insights to the research questions). Yin (1994) argues the evaluation of case studies should be based on the theoretical construct, not on the size of the sample, as is done in conventional quantitative strategies. Thus, the microfinance beneficiaries were chosen through purposive, network sampling for detailed interviewing, considering the purpose of the study that did not require representative large sampling. A total of 40 women beneficiaries were chosen taking 24 and 16 from the ACD and BRAC, respectively. 
In the first phase, microfinance beneficiaries were chosen for one-to-one in-depth interviews in order to examine the impact of the microfinance programs. The beneficiaries were selected according to their knowledge, experience, and period of involvement in the program. In the first instance, the researcher was introduced to the participants by the NGO staff, and the researcher then selected the respondents for further correspondence. Each and every Microfinance client was invited verbally to participate in the in-depth interview session. The researcher obtained a list of eighty beneficiaries from the selected NGOs but felt to have achieved the 'saturation point' with the 40th respondent.

One-to-one interviews with thirty women were conducted in their usual group meeting places and with ten women in the leader's house where they meet to pay their weekly or monthly installments. Microfinance beneficiaries were asked to answer a series of different open ended questions. The main aim of the in-depth interview was to collect qualitative data to examine the level of impact of the microfinance on women's empowerment. Each interview session lasted approximately an hour and a half, and was used to collect detailed case stories.

In the second phase, a number of focus group discussions (FGDs) were arranged with the microfinance beneficiaries. The FGDs were conducted to gain an understanding of and compare the participants' views about the details of the two microfinance programs. The women from the first phase were requested and did agree to take part in the second phase. This method served a useful purpose. It was a tool for collecting more in-depth information since people, especially women, in Bangladesh feel comfortable talking in a group (so the expectation was that they would add to their original one-to-one discussions). All in all eight FGDs were conducted with forty microfinance beneficiaries to explore and understand their views about the programs offered by the NGOs. Only five respondents were included in each group, so the participants could focus on the questions and avoid personal chatting. Microfinance beneficiaries from the two NGOs met for the FGDs on different dates. The FGDs were held in an open space of the village where they usually gather for their group meetings, in a group leader's house, or in open places under trees beside the respondent's houses. Each FGD took roughly 50-60 min. This method also helped the researcher get more in-depth and additional information regarding the microfinance beneficiaries' life transformation resulting from their borrowing from the microfinance program.

The researcher was very mindful of the power and cultural dynamics during the field investigation and visited the field areas repeatedly, spending the first couple of weeks only to befriend the participants. As a middle class urban person, the researcher initially faced difficulty understanding local power dynamics and culture. As the researcher was very careful in ensuring the collection of authentic qualitative data, she tried her level best to claim 'oneness' speaking the colloquial language, dressing in the local attires, appreciating the local cultural norms, and displaying friendly gestures. The interviewees were assured that the information would remain confidential and be used for exclusive academic purpose only. Any possible conflict of interest was seriously considered, making sure that the NGO officials were not in any way related to the researcher. Moreover, the NGO officials were not allowed to be present at the interviews or focus group discussions. Thus, the participants were 
offered an open and free environment to be honest and confident in expressing their thoughts.

\section{Data Analysis}

Through the interviews and data collection, a good understanding of the research issues and problems were obtained. The primary data were recorded and then transcribed and translated manually. NVIVO was used to store and examine data. For data processing and analyzing, thematic and conversational analysis were adopted following Denzin and Lincoln (2000). Themes (abstract constructs identified before, during and after data collection) were identified during the literature review, field works, and transcribing the field data. The general themes were derived from the literature and subthemes during the progression of the study (following Miles and Huberman 1994 cited in Denzin and Lincoln 2000).

All themes were reviewed, critically analyzed, and connected to the research questions to determine the final results (Miles and Huberman 1994). A codebook was made to detail the descriptions of each code (words or numbers) and record the inclusion and exclusion criteria and exemplars of the text for each theme. Every interview was analyzed separately, and finding was re-checked with the views of other respondents. A tabulation was prepared for the qualitative data. Data display was supported by narratives from the participants. The qualitative information was used to interpret the findings and to illustrate and support explanations and conclusions in the paper.

\section{Microfinance and Women in Bangladesh: An Overview}

Bangladesh is known as the birth place of microfinance. In the 1970s, a few experimental programs existed in Bangladesh to offer some small loans. These programs were based on solidarity group lending, where each member of the group provided guarantee for loan repayment for all other members. The origin of the group-based microfinance in its recent practical manifestation can be linked with numerous organizations founded in Bangladesh, especially the Grameen Bank founded by the Noble laureate Professor Mohammad Yunus.

In the 1980's, many NGOs, for example, the BRAC, began to develop their microfinance programs. The 1990's witnessed large-scale expansion of microfinance activities by many microfinance institutions (MFIs), following the Grameen Bank style microfinance approach. Originally, the pioneers at the Grameen Bank or BRAC targeted poverty alleviation offering small loans to the poorest of the poorthe rural women. Thus, the microfinance approach (small loans with very small weekly repayment facilities) became very popular, increasingly attracting the original target group and a development model for NGOs in the country (Ahmed 2003 cited in Pine 2010, p. 5).

According to the Bangladesh Microcredit Regulatory Authority at the end of 2011, Bangladesh had 576 microfinance institutions (MFIs); in addition, the major NGOs also offer microfinance programs. Nonetheless, the majority of microfinance 
beneficiaries belong to the largest MFI (the Grameen Bank serving $25 \%$ of the 26 million microfinance beneficiaries in the country) and four NGOs-ASA, BRAC, Proshika, and TMSS. Some regional NGOs (e.g., the ACD, RDRS) are also successful microfinance actors in the country (Mahtab 2007). The following discussion demonstrates the basic profiles of the two NGOs chosen as the instrumental cases for this study.

\section{Bangladesh Rural Advancement Committee (BRAC)}

The BRAC, formed in 1972 as a relief and rehabilitation organization, under the leadership of Sir Fazle Hasan Abed, has gradually transformed its mission, vision, and goals to work with people with extreme poverty, illiteracy, diseases, and other physical challenges. It is involved in promoting human rights, human dignity, and gender equity by building social acceptance, financial capability, and functional skills of the disadvantaged people, especially the women. Although the BRAC's focus is the individual, its survival is owed to the environment that allows disadvantaged women to break out of the cycle of poverty and hopelessness (cited in Nawaz 2011, p. 41).

Realizing the fundamental of the development truth that the livelihood of disadvantaged peoples would depend on the provision of sources of income not on relief, the BRAC initiated microloans. The disadvantaged women groups were offered the opportunity to borrow money for income generating activities. The program developed some innovative products and services over the years, initiated the present microfinance programs, and encouraged savings to meet unseen future crises (Majumder 2008, p. 55).

The BRAC launched its major credit activities in 1979 through rural credit projects (Rahman 2010) bringing the collateral-free loans and savings to the doorsteps of the disadvantaged people who had no access to the conventional banking system. Most of the borrowers of the microfinance program are women who use the loans to engage in various income generating activities, enabling them to build a livelihood for themselves and their families (Majumder 2008, p. 55). The BRAC, since 1974, has disbursed over $\$ 8.6$ billion to 5.2 million women borrowers who comprise $92 \%$ of all the borrowers (BRAC 2011, p. 28). Therefore, selecting the BRAC as an instrumental case study is a rational decision that would help answer the research questions.

\section{Association for Community Development (ACD)}

The Association for Community Development (ACD), a major NGO in Rajshahi district of Bangladesh, established by Salima Sarwar, that has gradually extended to other parts of the country, especially in the administrative divisions of Rangpur and Khulna (ACD 2011, p. 7). ACD, a grassroots human rights NGO established in 1989. They work with the disadvantaged and vulnerable people, and the victims of violence especially women and children, advocating for their human rights and social justice, and creating awareness.

The ACD launched its microfinance program for sustainable development but realized very quickly that without financial freedom of the disadvantaged group, the 
awareness raising or social mobilization programs would be ineffectual. For this reason, the ACD introduced their microfinance program as a core function of their operations and took it as a basis for operating other programs. It offers legal support, leadership training, and social awareness raising programs predominantly to the microfinance beneficiaries. The ACD's target groups of adolescents are generally the offspring of the microfinance beneficiaries (ACD 2011, p. 29).

The ACD has been operating a 'self-reliant' credit program for women since 1990 to support and empower the most disadvantaged group of women and adolescents living under the poverty line. The ACD is implementing the program in three different ways: (1) rural microfinance to empower women, (2) Small initiatives credit, and (3) Agricultural loan/credit (ACD 2011, p. 31). In the 5 years ending in 2010, the ACD distributed about 198 million taka (about $\$ 2.5$ million) to around 21 thousand women borrowers (ACD 2011, p. 31).

The ACD started microfinance programs 16 years after the BRAC and also has a focus on the disadvantaged group. The ACD, however, is a regional organization that is likely to approach the beneficiaries differently and to achieve different outcomes. Further, an online literature search did not reveal any research on the microfinance programs of the ACD. Thus, this research provides an opportunity to unpack the hidden stories surrounding this credit program and its impacts on the borrowers. The ACD and BRAC were selected as instrumental cases for this study for the above reasons.

\section{Women, Microfinance, and Empowerment: The Theoretical Paradox}

Microfinance is adapted as the most significant anti-poverty and women empowerment tool all over the world (Rahman 2007), but there are two paradoxical positions, one arguing in favor and the other against the positive impacts of microfinance on women. The controversy is especially pronounced when microfinance's impact on women's empowerment is considered. Hashemi et al. (1996) concluded that the Grameen Bank was very successful in women's empowerment in Bangladesh because of its central focus on credit as well as a skillful use of rules in loan program operations. Women's empowerment in their study was manifested in the women's higher mobility, ability to make household decisions, legal and political awareness, and ownership of productive assets. Sarkar (2000) reported that a woman's greater economic roles, as beneficiaries of the microfinance programs, definitely improve their status in the family. She stated that a majority of microfinance borrowers have access to more money, and even more importantly a greater say in the financial decision-making. Her study further asserted that most women borrowers claim a better position compared to the past as a result of their contribution to the household income.

Khandker (2005, p. 284) affirms that microfinance accounts for $40 \%$ of the entire reduction of moderate poverty in rural Bangladesh and that microfinance's spillover has $1 \%$ annual effect among non-participants with regard to poverty reduction for those living under moderate poverty and $1.3 \%$ annual reduction among those living under extreme poverty conditions. Some other authors (Rahman 
1996; Mahtab 2007; Hashemi et al. 1996) support the above arguments. In another study in Bahawalpur, Pakistan, Nawaz et al. (2012) found that microfinance effects women's empowerment because of their use of microfinance in various income generating activities, and that economic empowerment leads to increasing empowerment within the family and society.

Haque and Itohara (2009) conducted a research study on women's empowerment in a district (Gaibandha) in Bangladesh with a structured questionnaire survey of randomly selected respondents. They had chosen the BRAC, Grameen Bank, and Thengamara Mohila Sabuj Sangha (TMSS) for assessing their impact on women's empowerment. The result of the study reveals that only $21 \%$ of the women respondents experienced empowerment evidenced in the women's institutional participation, media exposure, and family land holdings. Interestingly enough, $69 \%$ of the 'empowered' women were active members of the microfinance programs, proving their effect on women's empowerment.

Yet again another study, Rahman et al. (2009) using a case study in Bangladesh, argued that the impact of microfinance on women borrowers' empowerment is related to the borrower's age, level of income and education. They concluded that educated women were most likely to make the right decisions increasing their empowerment impacts. Hence, microfinance involvement alone is not enough to empower women unless it is combined with education, and thus, non-borrower women can also experience empowerment.

Garikipati (2008) compares existing data on loan use with the borrowers' testimonies to highlight the impact lending to women has on household vulnerability and women's empowerment in India. She found that loans taken by women are often used for purchasing household assets or increasing income, to allow households to cope with a crisis. Nonetheless, the author argues, that without ownership of productive assets women expressed disempowerment because women's empowerment rests on successfully challenging the patriarchal grip on productive assets.

The studies cited here predominately were quantitative (Table 1). Overdependence on quantitative methods and statistical surveys limited the scope and depth of the study findings. The conceptual weakness of most studies is their focus only on the credit part of the microfinance programs. Very few studies followed a qualitative approach, and the rest failed to analyze the social aspects, especially the factors related to human capital such as health, education, and social networks. Only Kabeer (2003, p. 110) considers a wider social impact assessment of microfinance which is important for the microfinance sector's internal learning process. Further, while most of the earlier studies are delimited at micro level gender analysis, Kabeer (1996 cited in March et al. 1999, p. 105) looks beyond individual or the household level analysis stating that gender analysis should also be conducted at community, market, and state levels. She refers to these as "domains of impact" because societies comprised different institutional domains each with their own rules, norms, and practices which can be influenced by microfinance interventions in different ways. Kabeer (2003, p. 110) not only refers to the domains of impact but also highlights dimensions of change that should be assessed. Kabeer's argument that all 
Table 1 Literature on microfinance and women empowerment: quantitative approach; unidimensional focus

\begin{tabular}{|c|c|c|c|c|c|}
\hline Authors & Approaches & Sample & $\begin{array}{l}\text { Data collection } \\
\text { tool }\end{array}$ & Conclusions & Limitations \\
\hline $\begin{array}{c}\text { Haque and } \\
\text { Itohara } \\
(2009)\end{array}$ & Quantitative & 180 & $\begin{array}{l}\text { Structured } \\
\text { questionnaire }\end{array}$ & $\begin{array}{l}\text { MF is not very } \\
\text { empowering to } \\
\text { women; women } \\
\text { could attain } \\
\text { empowerment } \\
\text { either today or } \\
\text { tomorrow only by } \\
\text { money on } \\
\text { productive assets }\end{array}$ & $\begin{array}{l}\text { They overlooked } \\
\text { other factors, e.g., } \\
\text { age and education } \\
\text { that could have } \\
\text { significant impact } \\
\text { on women's } \\
\text { empowerment }\end{array}$ \\
\hline $\begin{array}{l}\text { Garikipati } \\
(2008)\end{array}$ & Quantitative & 117 & Questionnaire & $\begin{array}{l}\text { The loans procured } \\
\text { by women are often } \\
\text { used for } \\
\text { household's assets } \\
\text { and incomes. } \\
\text { Women's lack of } \\
\text { co-ownership of } \\
\text { household assets } \\
\text { disempowers } \\
\text { women }\end{array}$ & $\begin{array}{l}\text { Overlooked the } \\
\text { socio-cultural } \\
\text { context of a } \\
\text { particular country } \\
\text { despite the fact that } \\
\text { contextual } \\
\text { variables matter } \\
\text { significantly in } \\
\text { impact evaluation } \\
\text { of a policy }\end{array}$ \\
\hline $\begin{array}{c}\text { Rahman } \\
\text { et al. } \\
\text { (2009) }\end{array}$ & $\begin{array}{l}\text { Quasi } \\
\text { experimental }\end{array}$ & 387 & $\begin{array}{l}\text { Structured } \\
\text { questionnaire }\end{array}$ & $\begin{array}{l}\text { The non-borrowers } \\
\text { are equally } \\
\text { empowered; MF is } \\
\text { not enough to } \\
\text { empower women } \\
\text { unless it is } \\
\text { combined with } \\
\text { education }\end{array}$ & $\begin{array}{l}\text { Overlooked the } \\
\text { socio-cultural } \\
\text { context of a } \\
\text { particular country } \\
\text { despite the fact that } \\
\text { contextual } \\
\text { variables matter } \\
\text { significantly in } \\
\text { impact evaluation } \\
\text { of a policy }\end{array}$ \\
\hline $\begin{array}{l}\text { Sarkar } \\
\quad(2000)\end{array}$ & Quantitative & 143 & $\begin{array}{l}\text { Structured } \\
\text { questionnaire }\end{array}$ & $\begin{array}{l}\text { After their } \\
\text { involvement in MF } \\
\text { women have } \\
\text { money to spend for } \\
\text { themselves and } \\
\text { their families that } \\
\text { enhances their } \\
\text { position in the } \\
\text { family and society }\end{array}$ & $\begin{array}{l}\text { The author did not } \\
\text { take other socio- } \\
\text { economic factors } \\
\text { into consideration }\end{array}$ \\
\hline $\begin{array}{l}\text { Khandker } \\
\text { (2005) }\end{array}$ & Quantitative & 1638 & $\begin{array}{l}\text { Follow up } \\
\text { survey } \\
\text { though } \\
\text { structured } \\
\text { questions }\end{array}$ & $\begin{array}{l}\text { Access to } \\
\text { microfinance } \\
\text { contributes to } \\
\text { poverty reduction } \\
\text { at village level in } \\
\text { general and for } \\
\text { women in } \\
\text { particular. MF } \\
\text { helps both the } \\
\text { participants and } \\
\text { local economy }\end{array}$ & $\begin{array}{l}\text { Overdependence on } \\
\text { quantitative } \\
\text { methods limits the } \\
\text { scope and depth of } \\
\text { the study }\end{array}$ \\
\hline
\end{tabular}


Table 1 continued

\begin{tabular}{|c|c|c|c|c|c|}
\hline Authors & Approaches & Sample & $\begin{array}{l}\text { Data collection } \\
\text { tool }\end{array}$ & Conclusions & Limitations \\
\hline $\begin{array}{c}\text { Nawaz } \\
\text { et al. } \\
\text { (2012) }\end{array}$ & Quantitative & 94 & $\begin{array}{l}\text { Closed ended } \\
\text { questionnaire }\end{array}$ & $\begin{array}{l}\text { There is positive } \\
\text { relationship } \\
\text { between } \\
\text { microfinance and } \\
\text { women's } \\
\text { empowerment at } \\
\text { personal, family, } \\
\text { and economic } \\
\text { levels. Economic } \\
\text { empowerment of } \\
\text { women is most } \\
\text { influenced by MF }\end{array}$ & $\begin{array}{l}\text { Statistical analysis } \\
\text { suffers from under- } \\
\text { reporting and } \\
\text { inadequacy to } \\
\text { describe the } \\
\text { variation and } \\
\text { degree of } \\
\text { empowerment in } \\
\text { different contexts }\end{array}$ \\
\hline
\end{tabular}

Source Compiled by the author from the cited literature

of these issues are to be considered if an accurate picture of the impact of microfinance on women's empowerment is to be obtained is more relevant for the current study. By applying a qualitative research approach, this study aims to explore women borrowers' own understating and interpretation with regard to the impact of microfinance on their socio-economic empowerment.

\section{Research Findings and Analysis}

As discussed in the methodology, this study explores the extent and methods of women empowerment both economically and socially. The study explores women's participation in entrepreneurial activities, access to and control over resources, access to and control over income and expenditure, women's decision-making agency, mobility, and women's attitude and action toward male violence before and after their involvement in the microfinance programs. The following discussion demonstrates the findings of the study in each category of empowerment based on the indicators mentioned in the methodology.

\section{Indicators of Economic Empowerment of Women}

Women's economic empowerment in this paper is analyzed from the 'power to' dimension of power relationships. The analysis is to be based on three criteria, as mentioned in the methodology: women's involvement in income generating activities; access to and control over loan utilization; and control over income and expenditure. The goal was achieved through questions like 'who keeps household earnings' or 'who has a say in household expenditure.' Thus, entire empirical analysis in this paper is based on words rather than numbers. 


\section{Women's Involvement in Income Generating Activities}

The first criteria 'women's involvement in income generating activities,' as revealed from the field data, is depicted in Table 2. Based on the answers about their involvement in income generating activities, the women's 'entrepreneurship' roles are categorized into five groups. The data demonstrates that eight $(20 \%)$ women respondents can be clustered in Group 1 for their independent use of the borrowed money in 'income generating activities' (like petty business, tailoring, poultry farming, grocery shop keeping, dairy farming). Six (15\%) women invested the borrowed money jointly with the husband to run petty businesses and had full involvement in operating the businesses to be clustered in Group 2. These women's credit money worked as seed money in the jointly operated petty businesses. Five $(12.5 \%)$ women borrowers are clustered in Group 3 because they only work as assistants in their husbands' businesses with little or limited involvement in the business operation, while 19 women $(47.5 \%)$ borrowers invested the loan in on-thehomestead income generating activities separate from the husband's economic activity (which may also have partial support from the wife's microfinance loan) to be clustered in Group 4. These income generating activities include cattle rearing, dairy, poultry farming, sewing, making cow dung pellets for fuel, or katha (handstitched quilt) making. The study indicates that many women chose on-thehomestead entrepreneurial activities because they have to look after their families. So, women's domestic and family responsibility does not allow them to work outside their homes. Two (5\%) women borrowers are housewives, who handed over the microfinance to the husband to operate the business, to be clustered in Group 5.

These groupings help us understand the degree of women's empowerment from low to high levels. The following discussion demonstrates that women of group 1 and 2 are comparatively more empowered than those of group 3, 4, and 5 .

\section{Women's Control Over Loan Utilization, Income and Expenditure}

The field research revealed that $20 \%$ women (of Groups 3 and 5) transferred the full loan amount to the husband. Women of Group 4 (47.5\%) use the credit money

Table 2 Women's roles and involvement in 'income generating activities' (IGA)

\begin{tabular}{llll}
\hline $\begin{array}{l}\text { Category of women } \\
\text { loan borrowers }\end{array}$ & Roles and rate of involvement in IGA & $\begin{array}{l}\text { No of } \\
\text { respondents }\end{array}$ & Percentage \\
\hline Group-1 & Women as off-the-homestead entrepreneurs & 8 & $20 \%$ \\
Group-2 & Women as co-entrepreneurs & 6 & $15 \%$ \\
Group-3 & Women as husband's entrepreneurship supporter & 5 & $12.5 \%$ \\
Group-4 & Women as on-the-homestead entrepreneurs & 19 & $47.5 \%$ \\
Group-5 & Women as credit-liaison and housewives & 2 & $5 \%$ \\
Total & & 40 & 100 \\
\hline
\end{tabular}

Source prepared by the author from the field data 
for on-the-homestead entrepreneurship work, sometimes passing part of the loan to the husband to run a separate business. In spite of having access to the resources, these women have limited or no control over the loan utilization. Nevertheless, $35 \%$ women respondents are involved in some non-farming income generating activities either separately or jointly with the husband. These women not only have access to the loan but also have either partial or full control over its utilization. Women in Groups 1 and 2 are more economically empowered than those of Groups 3,4 , and 5 having more control over loan utilization. $15 \%$ women of Groups 1 and 2 are widows, divorced, or separated from the husbands. Being the head of the family, these women have all types of control, while $20 \%$ were either primary breadwinner of the family or had a good say in the family expenditure. All women of Groups 1 and 2 also received financial and social training from the NGOs. So women of Groups 1 and 2 exercised good control over loan utilization, income, and expenditure either independently or jointly with the husband.

The study confirms that women in Groups 3 and 4 had limited or no control over income and expenditure even as microfinance borrowers. In case of Group 3, women, having invested the loan amount, work just as assistants in the family business. As microfinance borrowers, women contribute physical labor in the businesses such as operating cooked food outlets, poultry or dairy farms. A woman (MC-25) operated a dairy farm with her husband accessing credit money (see Box $1)$.

The woman took care of the cows, and fed and milked them every day. However, she had no involvement in monetary matters and her husband kept all the accounts of the business. She supplied the milk, but the customers paid the money to her husband; so she had no idea about the business profit. Likewise, in case of operating the cooked food outlet, women would only do the cooking, and in the cases of dairy or poultry farming, the women would tend the cows or the chickens without any involvement in the monetary matters.

In case of Group 4, the women have limited control over loan utilization, income, and expenditure because sometimes women have to transfer part of their loan to the husband for businesses off-the-homestead. Women in this group earn money from their on-the-homestead income generating activities, but the major part of the family income is generally earned by the husband. Thus, women of this group have less control over family income and expenditure. Women in Group 5, being exclusively homemakers and away from any income generating activities did not have any control over the borrowed money. On the other hand, women in Groups 1 and 2 are

\section{Box 1}

Box 1: I am a regular loan receiver of the BRAC. We had to live a very measured life before getting involved in the BRAC. I took microloans six times. With my first loan I purchased a cow. My husband and I used to take care of that cow jointly. Gradually we developed a small dairy farm with the help of my second, third, fourth and fifth loans. From the beginning I used to hand over my loan to my husband. My husband usually kept 'hishab' (accounting) of our business. My husband used the loans to buy the cows, buy the cattle feed, and arrange repayment of the loan. No matter whether I handled the money or not, I had to work with my husband (MC-25 interview taken on 11.05.2012). 
in better position in controlling loan utilization, income, and expenditure than the women of other groups. These women, therefore, are comparatively more economically empowered than those of the other groups. Microfinance driven income-generating activities has brought some positive changes in exercising control over income and expenditure in some cases. Therefore, the study proves that although all women respondents have access to loans, not all of them have full control over its utilization or family expenses.

\section{Indicators of Socio-cultural Empowerment of Women}

Women's socio-cultural empowerment is studied from a 'power with' dimension of power relationship using criteria such as women's 'decision making agency,' 'mobility in public domain,' and 'changes in perception of and reaction towards spousal violence.' The 'decision making agency' refers to the woman's ability to take minor decisions like small household purchases or major decisions like leasing land (for share-cropping). Women's mobility in the public domain can be measured by women's freedom of movement, especially mobility for visiting the market (for purchasing essential goods), medical needs (to go for treatment), and travelling outside the village (for visiting cinema, restaurants, relative, and friends' houses). Changes in perception of and reaction toward spousal violence from the women's perspective are analyzed by considering the woman's perception of and reaction to both physical and verbal violence against women at the household arena.

\section{Decision-Making Agency}

The overall decision-making process within and beyond the households was explored by studying the decision-making process that was used in individual situations (not viewing all of them collectively in terms of a single indicator). The changes in the overall decision-making pattern across a range of different situations and their possible relationships to borrowing money from the NGOs were explored. One interesting finding was that the women's degree of involvement in decisionmaking depended on the categories of decisions to be made both within and beyond the family matters. For example, major decisions regarding large consumer purchases, house repairs, leasing of land (for share cropping), purchase of major assets, children's education, health or marriage, market transactions, family planning etc., were made either jointly or by the male members of the family, usually the husbands. Some respondents were the key decision makers in minor matters of the households such as small consumer purchases (food, clothes), choosing and purchasing livestock for rearing, simple health care matters for themselves and their children, household and other family matters etc.

For each area of decision-making, women respondents were asked 'who decided' about the particular issues in the recent past and whether they had experienced any differences in participating in the decision making since their involvement in microfinance. The study reveals that only $14(35 \%)$ respondents participated in making both major and minor decisions following their involvement in the microfinance program. On the other hand, $22(55 \%)$ women respondents 
participated in making minor decisions following their participation in microfinance. The remaining four $(10 \%)$ women respondents perceived no change to their decision making capacity. Ninety percent of the respondents acknowledged that their ability to make minor decisions improved after their involvement in microfinance. According to the field data, women made minor decisions (without seeking the husband's approval) about food purchases, simple health care matters for themselves and their children, and the household purchases. Changes in major decision-making patterns after the women's involvement to some extent were insignificant; major decision-making in the household remained under the male decision-making domain. The only change of any significance were the husband's preference for making joint decisions regarding major issues which were rare before the women's involvement in microfinance.

When asked 'why they thought that microfinance had a positive impact on their participation in decision making,' most women responded by firstly explaining that prior to joining in microfinance, they had less self-confidence as they had no money earning capacity and had to depend on the husband for every single matter. This situation changed once they initiated 'income generating activities' with the borrowed money. The study also revealed that except for Group 5 all other women (Groups 1, 2, 3, and 4) participated in making simple, family decisions more independently and confidently since their involvement in microfinance.

Further, though the responsibility for making major decisions remains with the male member of the family, the study revealed that women in Groups 1 and 2 participated more in making major decisions, regardless of the level of complexity of the issue. Apart from Group 5, in the families of Groups 3 and 4, major decisions are mostly taken either by the husband or jointly by the wife (as male dominance in disguise). Irrespective of the husband's propensity in heeding the wife's opinion, a culture of discussion has developed between the partners in the microfinance borrowing households. The research shows that changes are occurring. Nonetheless, radical changes from male dominated decision-making to female dominated decision-making will not happen overnight. There has been a process of shifting from the wife being marginalized with the husband exerting dominance toward a more actively shared role by both in household decision-making. This particular shift was found in the case of Groups 1 and 2 where the women took part in decision making process in order to establish their rights.

\section{Women's Mobility in Public Domain}

This study shows that prior to their involvement in a microfinance program, only eight $(20 \%)$ of the women respondents had the privilege of visiting public places on their own. Since their involvement in microfinance groups, around $32(80 \%)$ of them are now usually free to visit different places. This evidence demonstrates that the women's involvement in microfinance has facilitated their ability to move more freely in their neighborhood. Critics may argue that women's improved mobility outside their homes is merely representative of a generational social change; however, this research suggests that the women's participation in microfinance sped up social change in general and particularly in the women's lives. The respondents 
commented that their mothers' life styles were more confined than theirs, more importantly that their own lives were comparatively more confined prior to their participation in the microfinance groups. The field study revealed that women's participation in group meetings in particular, improved their ability to move more freely outside their homes into their immediate neighborhood. This freedom eventually led to their ability to visit other neighborhoods, the village markets, or hospital, if necessary. Twenty percent of the women respondents reported visiting different places outside their village to attend economic, social, or legal training programs offered by the NGOs. This initial liberty gradually increased their selfconfidence and gave them the courage to visit other public places. Their movement in the public domain is now increasingly being accepted by their family members and society in general.

One of the noteworthy findings of the study was that the women are still restricted in their ability to take part in activities such as visiting the cinema, city markets, or a relative's place outside the village. They can, however, now visit their children's schools or medical centers for treatment. This supports Hashemi et al.'s (1996) findings, who also found that women's freedom to visit hospitals independently increased since their participation in microfinance. Moreover, although most rural women are still restricted from visiting city areas, microfinance has brought about positive changes with respect to their ability to independently visit public places such as their children's schools or the village health complex, in case of an emergency.

\section{Spousal Violence Against Women}

The field study revealed that the majority of women respondents have gained increased awareness regarding domestic violence, especially that from the husband. They stated that domestic violence is now becoming less common. During the interviews, many women confirmed that although they had witnessed their mothers being physically assaulted by their fathers, they themselves are facing less of such violence from their partners. They also expressed that in any case, male domestic violence is unacceptable and stated their opinion that partners must have respect for each other. This study revealed that women's participation in microfinance had a positive impact on the incidence of domestic violence.

Women respondents admitted that their participation in loan initiated income generating activities and the training programs offered by the NGOs, assisted them to change their attitude toward male violence and masculine domination at home. The women challenged the masculine domination and supremacy in families where males make all the decisions and women have no rights. Their protests against male domination challenge the social norm. The microfinance program influenced the women's attitude in a number of ways. Women's economic contribution through involvement in income-generating activities using the credit money enhanced their confidence to protest against male domination or violence.

Women's family status seems to be related to their financial contribution to the family, with increases in both leading to less spousal violence. The study suggests that a woman's participation in income generating activities reduces poverty and her 
vulnerability to spousal violence at home. The respondents' participation in credit initiated income-generating activities makes them less economically dependent on their partners and more vocal against any violence. The woman's financial contribution to the family leads to better and improved gender relations. The study demonstrates that the women in Groups 1 and 2 made a stronger stance against domestic violence protesting violence at home as well as in the community. The examples (in Boxes 2, 3) of two women protesting domestic violence beyond their household affirm individual efforts in reducing violence at the community level.

The women's economic contribution to the family had a positive effect leading to better and improved gender relations. Almost all respondents of the study showed a clear stand against domestic violence. This could be a major step toward women's agency against oppression and subordination. The study suggests that economic empowerment led to social empowerment because the economically empowered women became confident at exercising agency, negotiating gender relations and protesting against domestic violence.

\section{Discussions and Policy Implications}

This qualitative research is intended to fill our knowledge gap on the subject, and gives the beneficiaries of the microfinance program an opportunity to 'voice' their perception of about their own 'microfinance-life,' especially of the resultant gender power transmutation. The field data suggest that the respondents did not utilize the microfinance in similar ways-the women entrepreneurs in Groups 1 and 2 outperformed borrowers in the other groups in utilizing microfinance more productively by being directly involved in 'income generating activities.' The former had greater control over loan utilization, income, and expenditure as well as capability in exercising decision making agency. They are also more mobile and did demonstrate a strong stance against domestic violence. The data confirm that there is a good nexus between economic and socio-cultural empowerment - these two groups of women are more economically solvent, did make higher financial contribution to the family, and did experience larger social empowerment.

It is important to identify the factors that helped these two groups of women attain higher advantages from microfinance membership and change perception about themselves and their place in society. The most significant factor that enabled the women of Groups 1 and 2 to outperform the others was the category of work

\section{Box 2}

Box 2: "I intervened twice in my neighbor's family matters. My next door neighbor used to seriously physically assault his wife. I went to support the woman and protest against the violent behavior. Although initially my husband did not willingly support me to interfere in another's family matter, he became supportive the second time when he realized that this cruel practice must be stopped. When the male neighbor was confronted by the both of us he stopped assaulting his wife and eventually gave us his promise that he would never assault her again in his life time."(MC-14, in-depth interview on 22.04.2012) 
Box 3

Box 3: "I protested against male dominance on one occasion after watching my next door neighbor constantly use controlling behavior with his wife. One day when he was assaulting his wife, I went to their home and asked him "why are you assaulting your wife?" In reply he said "it's our private business and we don't need anybody to interfere in our family affairs". But the woman rushed to me and wanted my protection saying "I do everything for my family but my husband never respects my feelings and he sometimes assaults me."I warned her husband that I would register a complaint against him in the legal aid section of BRAC if he did not change his behavior. I told him about some instances in other villages where women had filed cases against their husbands in BRAC's legal aid section. I also told him how the males were penalized for their offenses. My warning scared him and he stopped assaulting his wife and from then on I never heard any more commotions from their home."(MC-32, indepth interview on 12.05.2012)

they were involved in and its financial outcomes. The women's involvement in income generating activities off-the-homestead matters because working outside home is more empowering than working on-the-homestead because the former consequentially expands the women's control over loan utilization, income, and expenditure, as well as their 'decision making agency,' 'mobility in public domain,' and 'negative reaction towards spousal violence.' Working outside the home was more empowering for the women because it allowed the women to draw on their group and community networks to generate more social capital. The women of these two groups were also younger and more educated than those of the other groups, and had a more educated husband.

This may raise the question as to what is the exact impact of microfinance alone if other factors have contributed to women's empowerment. In response, it could be argued that other factors would not have come into play if microfinance was not available in the first instance. Many women respondents had never handled money before receiving microfinance. All the other factors were existent prior to their involvement in the microfinance programs. These women had no earning capacity (there was no social welfare, either) or ability to make any financial contribution to their families and had to plead for every single penny from the husband. They also had no freedom to make decisions, mobility, or appreciation of any decision (they dared to make) from the husband or any family member. Their circumstances improved with their access to the microfinance for income-generating activities, especially the women of groups 1 and 2 .

The factor that contributed most in helping women in groups 1 and 2 in experiencing much higher empowerment was the financial literacy training programs offered by the NGOs. The BRAC and ACD do not offer training services to all members. The study revealed that each and every women of group 1 and 2 were privileged in receiving financial and social training due to their age, education, length of membership, and their position within the group. These financial and social training opportunities enabled these women to utilize loans more productively than the other groups of women. The skills also provided training graduates with a greater understanding of the way money (family income or microfinance) could be used for productive purposes of their own, supporting the economic activities of their husband 
or others in the family, and advising about the overall financial situation of the family. This research reveals that a good level of socio-economic empowerment can only be possible if the women beneficiaries utilize their money themselves effectively and efficiently with competence in financial literacy (gained through the training programs offered by the microfinance agencies).

\section{Conclusion}

Microfinance, because of its focus on gender equality, justice, and empowerment, has been adopted as a development model to address global poverty in the twenty-first century. Adding to the debate of the impact of microfinance on women's empowerment, the paper suggests some positive impacts of microfinance on women's life and household power configuration. Many women who accessed microfinance, experienced empowerment only by their direct involvement in income generating activities with the loan amount. Economic empowerment promotes women's control over the family resources, and income and expenditure which further leads to social empowerment by enhancing women's decision-making agency and mobility in the public domain.

This paper focused on the multidimensional construct of empowerment and looked at other factors that contributed to the degree of empowerment. It seems financial literacy is equally if not more important than access to credit. Financial literacy enabled the training graduates to gain a greater understanding of the use of money (family income or microfinance) for productive purposes, independently utilizing money effectively and efficiently, keeping accounts, advising the husband or others in the family about economic activities, and advising about the overall financial situation of the family.

The paper contributes to the relevant knowledge in two ways: methodology and content. It adds to the methodology since most of the earlier studies focused mainly on quantitative methods and data analysis techniques which limited the scope and depth of the study findings. The current study used qualitative tools and techniques to gain in-depth knowledge and information regarding both women's economic and socio-cultural empowerment. This paper also adds to the content since most of the earlier studies focused predominantly on the financial construct of empowerment, ignoring the fact that empowerment is a complex construct which has to be evaluated from both economic and social perspectives. To what extent and how microfinance empowers women both economically and socially is also revealed, factors that many earlier studies overlooked. Most importantly, it reveals that financial literacy is fundamental and should be a compulsory training component of all microfinance programs.

Socio-economic training is important and should be provided to as many beneficiaries of the microfinance programs as possible. The field data substantiate the fact that the training programs create significant positive impacts on the life of women receiving microfinance and contribute to household power transformation. 
Open Access This article is distributed under the terms of the Creative Commons Attribution 4.0 International License (http://creativecommons.org/licenses/by/4.0/), which permits unrestricted use, distribution, and reproduction in any medium, provided you give appropriate credit to the original author(s) and the source, provide a link to the Creative Commons license, and indicate if changes were made.

\section{References}

ACD. (2011). Annual Report, 2011. Rajshahi: ACD.

Basargekar, P. (2010). Measuring effectiveness of social capital in microfinance: A case study of urban microfinance program in India. International Journal of Social Enquiry, 3(2), 25-43.

Begum, A. (2003). Government-NGO interface in development management: Experiences of selected collaboration models in Bangladesh. Dhaka: A. H. Development Publishing House.

BRAC. (2011). Annual Report, 2011. Dhaka: BRAC.

Denzin, N. K., \& Lincoln, Y. S. (2000). Handbook of qualitative research. California: Sage Publishing.

Garikipati, S. (2008). The impact of lending to women on household vulnerability and women's empowerment: Evidence from India. World Development, 36(12), 2620-2642.

Goswami, A. (1998). Empowerment of women in Bangladesh. Journal of Empowerment, 5(1), 45-70.

Haque, M., \& Itohara, Y. (2009). Women empowerment through participation in micro-credit programme: A case study from Bangladesh. Journal of Social Science, 5(3), 244-250.

Hashemi, S. M., Schule, S. R., \& Riley, A. P. (1996). Rural credit programs and women's empowerment in Bangladesh. World Development, 24(4), 635-654.

Kabeer, N. (1996). Women, wages and intra-household power relations in urban Bangladesh. Development and Change, 28, 261-302.

Kabeer, N. (1998). Money can't buy me love, Re-evaluating gender, credit and empowerment in rural Bangladesh. Brighton: Institute of Development Studies, University of Sussex.

Kabeer, N. (2003). Gender mainstreaming in poverty eradication and the millennium development goals: A handbook for policy makers and other stakeholders. Retrieved 02 October, 2013, from http://web. idrc.ca/openebooks/067-5/.

Khandker, S. R. (2005). Microfinance and poverty: Evidence using panel data from Bangladesh. World Bank Economic Review, 19(2), 55-58.

Mahtab, N. (2007). Women in Bangladesh, from inequality to empowerment. Dhaka: A H Development Publishing House.

Majumder, M. H. K. (2008). Socio Economic Impact of Microcredit in Bangladesh; A critical Evaluation of the Microcredit program of Grameen Bank. Unpublished PhD thesis, University of Rajshahi, Bangladesh.

Malhotra, A., Schule, S. R., \& Boender, C. (2002). Measuring women's empowerment as a variable in international development. Background paper prepared for the World Bank workshop on poverty and gender: New Perspective.

March, C., Smyth, I., \& Mukhopadhyay, M. (1999). A guide to gender-analysis frameworks. Oxford: Oxfam Publishing.

Miles, M. B., \& Huberman, A. M. (1994). An expanded source book qualitative data analysis. London: Sage.

Nawaz, F. (2011). Strengthening awareness among rural adolescent girls in Bangladesh: A case study on adolescent development program of BRAC. Germany: Lambert Academic Publishing.

Nawaz, N., Jahanian, A., \& Manzoor, S. W. (2012). Empowering women through microcredit: A case study of Tameer microfinance bank, Bahawalpur. Journal of Economics and Sustainable Development, 3(6), 17-21.

Pine, D. (2010). The microfinance sector in Bangladesh: Innovation or stagnation. Unpublished BA thesis, University of Zurich, Zurich, Switzerland.

Rahman, A. (1996). Microcredit initiative for equitable and sustainable development: Who pays? World Development, 27(1), 67-82.

Rahman, S. (2007). The impact of Microcredit on poverty and women's empowerment: A case study of Bangladesh. An unpublished Doctoral Dissertation, School of Economic and Finance, University of Western Sydney, Australia.

Rahman, A. K. M. M. (2010). NGO and development: Myth and reality. Dhaka: AH Development Publishing House. 
Rahman, S., Junankar, P. N., \& Mallik, G. (2009). Factors influencing women's empowerment on microcredit borrowers: A case study in Bangladesh. Journal of the Asia Pacific Economy, 14(3), 287-303.

Sarkar, A. R. (2000). Women in microcredit and their empowerment-Case study of BRAC societies under Sherpur Upazila of Bogra District. Bogra: Tajma Art Press.

Siddiquee, N., \& Faroqi, M. (2009). Holding the giants to account? Constraints on NGO accountability in Bangladesh. Asian Journal of Political Science, 17(3), 243-264.

Yin, R. K. (1994). Case study research: Design and methods. Thousand Oaks: Sage. 